Gut, 1982, 23, 927-930

\title{
Lymphocyte subpopulation in acute viral hepatitis
}

\author{
U DATTA, S SEHGAL, S R PAL, K DHALL, S SINGH, and D V DATTA* \\ From the Departments of Immunopathology, Obstetrics and Gynaecology, Virology and Hepatology, \\ Postgraduate Institute of Medical Education and Research, Chandigarh, India
}

SUMmARY Studies of peripheral blood lymphocytes were performed in 41 patients with acute viral hepatitis, in grade III-IV coma; 16 patients were in the third trimester of pregnancy. There were significant reductions in absolute lymphocyte count and $T$ cell number in patients who succumbed to the disease, when compared with those who survived. B cell counts were similar in the two groups and migration inhibition test with BCG antigen was normal. It is postulated that a decrease in the number of cells interacting in cell-mediated immune reactions is related to prognosis in acute viral hepatitis.

Acute viral hepatitis is generally a self-limiting disease with complete recovery, but rarely it takes a fulminant course or progresses to chronic hepatitis. As in any infectious disease, the outcome is likely to be intimately linked with the immunological responses of the host and, in addition to humoral antibodies, cell-mediated immune responses are vital for resistance in viral infections. There is discrepancy in the literature with regard to observations on the number of cells associated with cell-mediated immunity in viral hepatitis ${ }^{12} 3$ and in most of the patients described in these studies, symptoms were of long duration and the cases could not therefore be considered genuinely acute hepatitis. In the work described in this paper, $T$ and B cells were enumerated in patients with acute viral hepatitis and later the results correlated with the outcome of the disease. In most patients the duration of symptoms was under two weeks.

\section{Methods}

This work was carried out during the period 1975-78.

\section{Controls}

Fifteen laboratory personnel age matched to the patients, and 15 pregnant women in the third trimester of pregnancy acted as controls.

\footnotetext{
* Deceased

Received for publication 18 February 1982
}

\section{Patients}

All of the 41 patients were admitted, seriously ill with grade III to IV hepatic coma. The period of prodromal symptoms was short and blood samples were collected immediately after admission, before institution of any therapy. Ten millilitres of heparinised blood was collected for enumeration of lymphocytes, $2 \mathrm{ml}$ blood taken in EDTA for total and differential count, and $2 \mathrm{ml}$ blood allowed to clot, serum separated, and the serum used for electrophoresis and for screening for hepatitis associated antigen.

\section{HBs $A g$}

In 40 of the patients, discontinuous counter-current immunoelectrophoresis (DCIE) as previously described $^{4}$ was used for HBs antigen detection.

\section{Lymphocyte studies}

Lymphocytes were separated from whole blood by using a Ficoll Hypaque gradient $;^{5} \mathrm{~T}$ cells were measured by the method of Wybran and Fundenberg ${ }^{6}$ in which lymphocytes were allowed to form spontaneous rosettes with sheep red cells; B cells were detected by the method of Bianco et al, ${ }^{7}$ by the formation of EAC rosettes.

\section{Migration inhibition test}

A migration inhibition test was performed using BCG as antigen, by the capillary tube method of Soborg and Bendixen. ${ }^{8}$ The area of migration of lymphocytes in test and control cultures were measured by plotting on graph paper after 
projection of the plate on a screen.

$$
\text { Migration inhibition }=\frac{\text { Test }(\text { with BCG }) \times 100}{\text { Control }(\text { without } \mathrm{BCG})}
$$

\section{Results}

Of the 41 patients with acute hepatitis, 28 were female and of these 16 were in the last trimester of pregnancy. In 25 patients duration of symptoms ranged from one to 10 days; in 13 patients symptoms had been present for 10 to 20 days; and in five patients, 20 to 30 days. Eighteen patients died and the relationship between mortality and sex is shown in Table 1. There were no differences in mortality between pregnant and non-pregnant females, and between females and males. Furthermore, there was no significant correlation between mortality and socioeconomic background (Table 2). The evaluation of the socioeconomic status was based on family income per month and the educational standard of the patient or the spouse.

There were no differences between controls and hepatitis patients with respect to total lymphocyte counts (Table 3); in the subgroup of patients who succumbed to the disease, however, there was a statistically significant $(p<0.01)$ reduction in peripheral blood lymphocyte count. In contrast, patients who recovered had a modest increase in lymphocyte counts, although this was not statistically significant. There were no differences in the values obtained in normal females, pregnant females, or pregnant females with viral hepatitis (Table 4).

Peripheral blood $\mathrm{T}$ cell counts 'were also not significantly different from controls when the total group of acute hepatitis patients was considered. Those patients who died, however, had much lower $T$ cell counts $(p<0.01)$ when compared with those who recovered. Once again, pregnancy had no effect on the pattern of cell counts or on the outcome of disease.

There were no significant differences in B cell counts in any of the groups, and in the 30 patients in
Table 1 Mortality in acute hepatitis

\begin{tabular}{lll}
\hline Groups & $\begin{array}{l}\text { No. dead/ } \\
\text { no. studied }\end{array}$ & $\begin{array}{l}\text { Percent } \\
\text { mortality }\end{array}$ \\
\hline Males & $6 / 13$ & 43 \\
Non-pregnant females & $7 / 13$ & 39 \\
Pregnant females & $5 / 15$ & 33 \\
\hline
\end{tabular}

whom migration inhibition tests were done (Figure) no differences between acute hepatitis and controls were detected $(p>0 \cdot 05)$.

HBs antigen was detected in seven of the 40 patients, and of these three died and four recovered.

\section{Discussion}

This study has shown that patients who die of acute viral hepatitis have decreased numbers of lymphocytes in peripheral blood. This is primarily due to a decrease in the number of $T$ cells and is contrasted with a slight increase in both total lymphocyte count and $T$ cell count in the patients who recovered from acute hepatitis. Although absolute numbers of $T$ cells were decreased, the capacity of the cells to respond to an antigenic stimulus (BCG) remained unimpaired, as evidenced by a normal response in a migration inhibition test. It therefore seems likely that a decrease in the number of immunocompetent cells is more significant in the ultimate outcome of the disease than an impairment in their function.

Disturbances in lymphocyte function ${ }^{1}$ and reduction in number of blood lymphocytes ${ }^{2}{ }^{3}$ have been previously reported in patients with so-called acute hepatitis. The first paper, however, can be criticised in that the authors did not include truly acute cases, many of the patients having had symptoms for more than two months. ${ }^{1}$ Furthermore, Dehoratuis and his colleagues included a very heterogeneous group of patients, some having jaundice for up to 16 weeks before study.

Table 2 Relationship between socioeconomic status and mortality

\begin{tabular}{|c|c|c|c|c|c|c|c|c|c|c|c|c|}
\hline \multirow[b]{3}{*}{ Group } & \multicolumn{12}{|c|}{ Economic status } \\
\hline & \multicolumn{4}{|l|}{ Low } & \multicolumn{4}{|c|}{ Middle } & \multicolumn{4}{|c|}{ High } \\
\hline & $\overline{T N}$ & $S$ & $D$ & $\%$ & $\overline{T N}$ & $S$ & $D$ & $\%$ & $\overline{T N}$ & $S$ & $D$ & $\%$ \\
\hline $\begin{array}{l}\text { Pregnant } \\
\text { Control }\end{array}$ & $\begin{array}{l}13 \\
11\end{array}$ & $\begin{array}{l}10 \\
5\end{array}$ & $\begin{array}{l}3 \\
6\end{array}$ & $\begin{array}{l}23 \cdot 07 \\
54 \cdot 54\end{array}$ & $\begin{array}{l}7 \\
7\end{array}$ & $\begin{array}{l}4 \\
5\end{array}$ & $\begin{array}{l}3 \\
2\end{array}$ & $\begin{array}{l}42 \cdot 85 \\
28 \cdot 5\end{array}$ & $\begin{array}{l}6 \\
2\end{array}$ & $\begin{array}{l}5 \\
1\end{array}$ & $\begin{array}{l}1 \\
1\end{array}$ & $\begin{array}{l}16 \cdot 67 \\
50\end{array}$ \\
\hline
\end{tabular}

$\mathrm{TN}=$ total number. $\mathrm{S}=$ survivals. $\mathrm{D}=$ deaths. (Meenakshi Saran $e \mathrm{al}^{14}$ ). 
Table 3 Subpopulation of cells in hepatitis with coma

\begin{tabular}{|c|c|c|c|}
\hline Patients & No. & $\begin{array}{l}\text { Lymphocytes } \\
\left(\text { cells } / \mathrm{mm}^{3}\right)\end{array}$ & $\begin{array}{l}T \text { cells } \\
\left(\text { cells } / \mathrm{mm}^{3}\right)\end{array}$ \\
\hline Controls & 16 & $2653 \pm 972$ & $1434 \pm 947$ \\
\hline Acute hepatitis & 41 & $\begin{array}{l}2497 \pm 1112 \\
>0.05\end{array}$ & $\begin{array}{l}1267 \pm 652 \\
>0.05\end{array}$ \\
\hline Hepatitis recovered & 23 & $\begin{array}{l}2965 \pm 1159 \\
>0.05\end{array}$ & $\begin{array}{l}1564 \pm 690 \\
>0.05\end{array}$ \\
\hline Hepatitis & 18 & $\begin{array}{l}1878 \pm 671 \\
<0.01\end{array}$ & $\begin{array}{l}890 \pm 341 \\
<0.01\end{array}$ \\
\hline
\end{tabular}

Mahalanbis and his colleagues from India have also reported that the number of $T$ cells is reduced in acute hepatitis, but they expressed the results in terms of percentages: it is now recognised that it is essential to report these results in terms of absolute cell counts. ${ }^{9}$

Of the 41 patients included in the present study, seven were found to be positive for hepatitis B surface antigen by a discontinuous counter-current electrophoresis technique - an incidence similar to a previous study from Northern India. ${ }^{4}$ This technique will have underestimated the true number of positive cases but a more sensitive technique for HBs antigen detection was not available to us.

There was a significant excess of female patients in this study, and more than half of the females were pregnant. This pattern of cases is due to the special interest of one of us (DVD), but in any event there were no differences in lymphocyte and $T$ cell numbers when the patients with hepatitis in the last trimester of pregnancy were compared with normal age-matched females. There is still controversy as to the immunological changes in normal pregnancy, but in a previous study for this laboratory ${ }^{10}$ we have found no alterations in $T$ cell numbers in the last trimester of normal pregnancy, and the present study corroborates our earlier observation.

Hepatitis in pregnancy has also been a subject of debate for years. There have been contrasting reports of severity of hepatitis and mortality rate in

Table 4 Subpopulation of cells in hepatic coma in females

\begin{tabular}{|c|c|c|c|}
\hline Patients & No. & $\begin{array}{l}\text { Lymphocytes } \\
\left.\text { (cells/mm } \mathrm{mm}^{3}\right)\end{array}$ & $\begin{array}{l}\text { T cells } \\
(\text { cells/cumm) }\end{array}$ \\
\hline Normal females & 13 & $2712 \pm 1170$ & $1520 \pm 672$ \\
\hline Normal pregnant & 14 & $\begin{array}{l}2859 \pm 717 \\
>0.05\end{array}$ & $\begin{array}{l}1638 \pm 454 \\
>0.05\end{array}$ \\
\hline Pregnant with hepatitis & 15 & $\begin{array}{l}2873 \pm 1435 \\
>0.05\end{array}$ & $\begin{array}{l}1772 \pm 1037 \\
>0.05\end{array}$ \\
\hline Recovered & 10 & $2963 \pm 255$ & $1774 \pm 505$ \\
\hline Died & 5 & $\begin{array}{l}1841 \pm 1029 \\
<0.05\end{array}$ & $\begin{array}{l}1031 \pm 655 \\
<0.05\end{array}$ \\
\hline
\end{tabular}

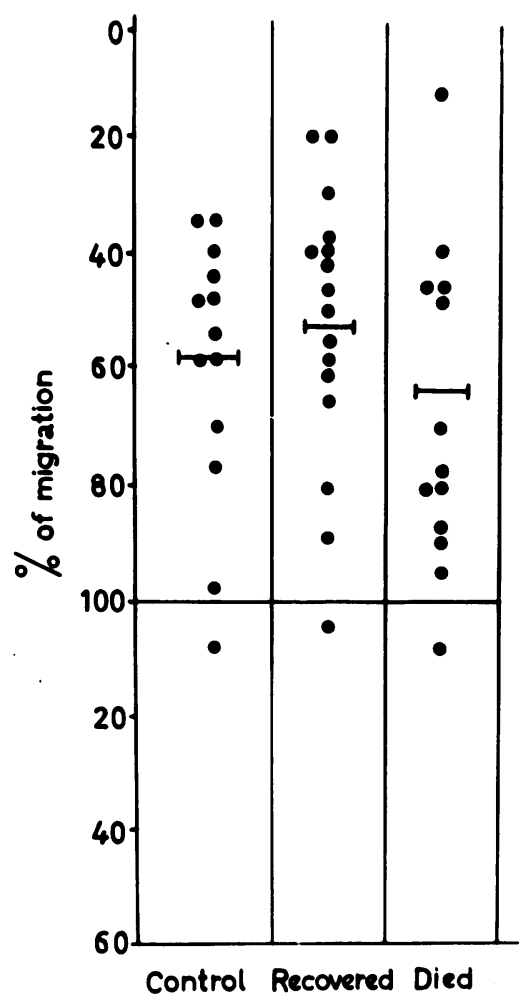

Figure Migratory response of leucocytes to BCG antigen in viral hepatitis

acute hepatitis associated with pregnancy. ${ }^{11-13}$ In contrast with what occurs in Western countries, it has been reported from India that the course of the disease is more severe in pregnancy, ${ }^{8}$ and poor nutrition may be one of the mechanisms. A prospective study from this Institute ${ }^{14}{ }^{15}$ however, showed no significant difference in the severity of hepatitis, and in the mortality, when pregnant and non-pregnant patients were compared, irrespective of their social status.

This present report supports our previous observations that $T$ cell numbers are normal in pregnancy, and that pregnancy has no specific deleterious effect on patients with hepatitis.

In conclusion, we have demonstrated that the total lymphocyte population is depleted in many patients with acute hepatitis, and this primarily affects $\mathrm{T}$ cells, which do, however, retain the capacity to generate lymphokines. The above observations suggest a possible role of $T$ cells in protecting the host from fulminant viral infection.

The authors are grateful to Dr A Parashar for statistical analysis and to Dr A G S Pathania for valuable suggestions. 


\section{References}

1 Gustino V, Dudley FJ, Sherlock S. Thymus dependent lymphocyte functions in patients with hepatitis associated antigen. Lancet 1972; 2: 850-53.

2 DeHoratuis Raphael J, Strickland RG, Williams RC. T and B lymphocytes in acute and chronic hepatitis. Clin Immunol Immunopathol 1974; 2: 353-60.

3 Mohalanbis D, Jalan KN, Maitra TK, Agarwal SK, Bhattacharya S. Peripheral $\mathrm{T}$ and $\mathrm{B}$ cell rosetting in acute infective hepatitis and evaluation of a plasma inhibitory factor. Indian J Med Res 1976; 64: 1723-9.

$4 \mathrm{Pal}$ SR, Chitkara NL, Choudhury S, Datta DV, Deodhar SD, Chhuttani PN. Hepatitis B virus infection in Northern India. Prevalence, subtypes and seasonal variation. Bull WHO 1974; 51: 13-17.

5 Boyum A. Separation of leucocytes from blood and bone marrow. Scand J Clin Lab Invest 1968; suppl 97: 21: 51-76.

6 Wybran J, Fuddenberg HH. Thymus derived rosette forming cells in various human disease states: cancer, lymphoma, bacterial and viral infections. J Clin Invest 1973; 52: 1026-32.

7 Biano C, Patrick R, Nuzzenweig V. A population of lymphocytes bearing a membrane receptor antigenantibody complex. J Exp Med 1970; 132: 702-20.

8 Soborg M, Bendixen G. Human lymphocyte migration parameter of hyper-sensitivity. Acta Med Scand 1967; 181: 247-56.

9 Hayward A, Greaves MF. Human T and B lymphocyte population in blood. In: Thompson RA, ed. Recent advances in clinical immunology. Edinburgh: Churchill Livingstone, 1977: 149-80.

10 Grewal G, Sehgal S, Aikat BK, Gupta AN. Cell mediated immunity in pregnant patients with and without previous history of spontaneous abortions. $\mathrm{Br} \mathrm{J}$ Obstet Gynec 1978; 85: 221-4.

11 Bennet N Mek, Foches JA, Lucas CR, Kugers A. Infective hepatitis and pregnancy. Analysis of liver function test results. Med J Aust 1967; 2: 974.

12 Malkani PK, Grewal AK. Observations on infective hepatitis in pregnancy. Indian J Med Res 1957; suppl: 45: $77-84$.

13 Borhanmanesh F, Haghighi P, Hekmat K, Rezaiazadeh OG, Khavami AG. Viral hepatitis during pregnancy severity and effect of gestation. Gastroenterology 1973; 64: 304-12.

14 Meenakshi Saran, Gupta AN, Bhagwat AG, Datta DV. Hepatitis in pregnancy-proceedings of the seminar held under auspices of the Research Society of Sir H N Hospital, Bombay, 1975. In: Vakil BJ, Shah SC, eds. Hepatitis. 41-9.

15 Datta DV. Viral hepatitis. J Assoc Physicians India 1977; 25: 325-30. 